\title{
PERFORMANCE OF MIXED CROPPING OF LENTIL WITH COWPEA UNDER VARIABLE SEEDING RATIOS
}

\author{
I. S. M. Farhad ${ }^{1 *}$, E. Jahan', M. A. Rahman', M.G.Azam ${ }^{4}$ and T. A. Mujahidi ${ }^{5}$ \\ ${ }^{1}$ Soil Science Division, BARI, Gazipur, Bangladesh, \\ ${ }^{2}$ Department of Agricultural Chemistry, SAU, Dhaka, Bangladesh, \\ ${ }^{3}$ Department of Agronomy,SAU, Dhaka Bangladesh, \\ ${ }^{4}$ RARS, BARI, Hathazari, Chittagong, Bangladesh, \\ ${ }^{5}$ Plant Breeding Division, BARI, Gazipur, Bangladesh \\ *Corresponding author, E-mail:farhadsau@gmail.com
}

(Received: 31 January 2018, Accepted: 20 March 2018)

Keywords: Mixed cropping, Lentil, Cowpea and Equivalent yield

\begin{abstract}
The field experiment was carried out at South Lemua, MLT site, Feni (AEZ 19) during Rabi season of 2015-16 to evaluate the performance of lentil as mixed crop with cowpea under variable seeding ratio. The treatment combinations used for the experiment were $\mathrm{T}_{1}=$ Sole Lentil $(100 \%) @ 40 \mathrm{~kg}$ seed ha ${ }^{-1}, \mathrm{~T}_{2}=$ Sole Cowpea $(100 \%)$ @ $45 \mathrm{~kg}$ seed $\mathrm{ha}^{-1}, \mathrm{~T}_{3}=\operatorname{Lentil}(100 \%)+$ Cowpea $(10 \%), \mathrm{T}_{4}=\operatorname{Lentil}(100 \%)+$ Cowpea $(20 \%)$ and $\mathrm{T}_{5}=$ Lentil $(100 \%)+$ Cowpea $(30 \%)$. Lentil var. BARIMashur-6 and cowpea variety BARI Felon-1 were used in this study. The yield of lentil decreased with the increase of cowpea population in the mixed cropping situation. All the mixed cropping combinations showed higher lentil equivalent yield (LEY), land equivalent ratio (LER), net return and benefit cost ratio (BCR) than sole cropping. The highest lentil equivalent yield (1438 $\left.\mathrm{kg} \mathrm{ha}^{-1}\right)$ and maximum land equivalent ratio (1.24) were observed in $\mathrm{T}_{4}$ treatment. Cost and return analysis showed that the highest net return (Tk. 77,890 ha ${ }^{-1}$ ) was found in $\mathrm{T}_{4}$ treatment while sole cowpea gave the lowest net return $\left(\mathrm{Tk} .7530 \mathrm{ha}^{-1}\right)$. The highest benefit cost ratio (3.09) was recorded from lentil $(100 \%)+$ cowpea $(20 \%)$ whereas the minimum (1.21) from sole cowpea.
\end{abstract}

\section{Introduction}

In Bangladesh, pulses play a vital role in agriculture as well as in human diets. The average yield of pulses is $1.01 \mathrm{t} \mathrm{ha}^{-1}$, which is low compared to other neighboring countries (BBS, 2016).The area under pulse crops has declined while the area under rice production has increased (Das and Kabir, 2016). But the demand of pulses is increasing continuously. Lentil is the most popular pulse crop in Bangladesh. It plays an important role in human diets and also in improving soil fertility by fixing atmospheric nitrogen. On the other hand, cowpea (locally known as felon dahl) is very popular to the people of Noakhali. Farmers' usually use local variety and get poor yield due to low yield potentiality. BARI has developed some high yielding varieties of lentil and Cowpea. Both lentil and cowpea are cultivated as sole crop throughout the country in Rabi season and sometimes as mixed crop in farmers' field. It is observed that, some farmers of Noakhali region cultivate lentil as a mixed crop with cowpea without determining benefit, cost and return and land use efficiency. Generally, farmers do not maintain proper seeding ratio of mixed crop, planting time and other management practices. Mixed cropping reduces the risk of total crop failure as two or crops that are more different are cultivated simultaneously in the same field. This mixed cropping system is already practicing in the farmer's field at Feni area. However, the farmers do not maintain the appropriate seedlings ration and thus, the crop with unnecessarily high population suppress the growth of other one. 
The present study was, therefore, undertaken to determine the most profitable mixed crop combination of lentil and cowpea.

\section{Materials and Methods}

The experiment was carried out at South Lemua, MLT site, Feni during Rabi season of 2015-16. The soils of the experimental areas belong to the Young Meghna River Estuarine Flood Plain (AEZ 19). The soils of the experimental plots were clay loam in texture. The experiment was laid out in Randomized Complete Block design with six dispersed replications. It was consisted with five treatments as follows: $\mathrm{T}_{1}=$ Sole Lentil1 $(100 \%) @$ seed rate $40 \mathrm{~kg} \mathrm{ha}^{-1}, \mathrm{~T}_{2}=$ Sole Cowpea (100\%) @ seed rate $45 \mathrm{~kg} \mathrm{ha}^{-1}, \mathrm{~T}_{3}=$ Lentil $(100 \%)+$ Cowpea $(10 \%), \mathrm{T}_{4}=$ Lentil $(100$ $\%)+$ Cowpea $(20 \%)$ and $\mathrm{T}_{5}=$ Lentil $(100 \%)+$ Cowpea $(30 \%)$. According to the treatments, seeds of Lentil (BARI Mashur-6) and Cowpea (BARI Felon-1) were broadcasted on 7-11 December, 2015. The unit plot size was $40 \mathrm{~m}^{2}(10 \mathrm{~m} \mathrm{x} 4 \mathrm{~m})$. The lands were fertilized with 21 , $18,20,7,1.5$ and $1.5 \mathrm{~kg}$ N-P-K-S-Zn-B ha-1, respectively. Two-third urea and entire amount of all fertilizers were applied during final land preparation as basal in all the treatment combination and rest $1 / 3^{\text {rd }}$ urea was applied as top dress at about 30 days after broadcasting. One weeding was done at 30 days of sowing. A systemic insecticide (cypermethrene) was sprayed at seedling stage to control aphids and thrips. Lentil was harvested on 10-12 March, 2016 whereas, cowpea harvesting started on 8 March and continued up to 13 April, 2016. Data on the different crop parameters were collected from the 10 sample plants and then average was taken which was further analyzed by computer program Crop Stat. Lentil equivalent yield (LEY), land equivalent ratio (LER) and economic analysis were calculated to ascertain the efficiency of mixed cropping. Lentil equivalent yield was calculated by converting yield of mixed crops to the yield of lentil on the basis of prevailing market prices of individual crops. Lentil equivalent yield (LEY) was calculated after Bandyopadhyay, 1984.

\section{Lentil equivalent yield $=\underline{\text { Yield of cowpea }\left(\mathrm{Kg} \mathrm{ha}^{-1}\right) \times \text { Price of cowpea }\left(\mathrm{Tk} . \mathrm{Kg}^{-1}\right)}$} Price of lentil (Tk. $\left.\mathrm{Kg}^{-1}\right)$

The treatments were evaluated in terms of land equivalent ratio (LER) using the following formula of Willey (1981).

Land equivalent ratio $=\frac{\text { Yield of intercropped lentil }}{\text { Yield of solecropped lentil }}+\frac{\text { Yield of intercropped cow pea }}{\text { Yield of solecropped cowpea }}$

\section{Results and Discussions}

\section{Seed yield and yield attributes of lentil}

Yield and yield attributes of lentil are presented in the Table 1. Results revealed that plant populations of lentil were varied with the percent amount of cowpea seeds used among the treatments. These results comply with that of findings Bhowal et al. (2014), who observed that plant populations of lentil were varied with the percent amount of mustard seeds used among the treatments. The highest number of pod plant ${ }^{-1}(28)$ was recorded in $T_{1}$ (sole Lentil) followed by $\mathrm{T}_{3}$ (26). The lowest number of pod plant ${ }^{-1}(25)$ was obtained from $\mathrm{T}_{4}$ and $\mathrm{T}_{5}$ treatment. The highest 1000- seed weight (22.4) was recorded in $\mathrm{T}_{1}$ followed by $\mathrm{T}_{3}(21.9)$ and $\mathrm{T}_{4}$ (21.7). The lowest 1000 seed weight (21.4) was recorded in $\mathrm{T}_{5}$ treatment where Lentil $(100 \%)+$ Cowpea $(30 \%)$ broadcasted.

Table 1. Seed yield and yield attributes of lentil as a mixed crop with cowpea at South Lemua under MLT site, Feni during Rabi season of 2015-16 


\begin{tabular}{lccccc}
\hline Treatments & $\begin{array}{c}\text { Plant } \\
\text { population } \mathrm{m}^{-2} \\
(\text { no. })\end{array}$ & $\begin{array}{c}\text { Plant } \\
\text { height } \\
(\mathrm{cm})\end{array}$ & $\begin{array}{c}\text { Pods plant } \\
(\text { no. })\end{array}$ & $\begin{array}{c}1000 \text { - seeds } \\
\text { weight } \\
(\mathrm{g})\end{array}$ & $\begin{array}{c}\text { Seed yield } \\
\left(\mathrm{Kg} \mathrm{ha}^{-1}\right)\end{array}$ \\
\hline $\mathrm{T}_{1}$ & 190 & 27.5 & 28 & 22.4 & 1325 \\
$\mathrm{~T}_{3}$ & 186 & 26.8 & 26 & 21.9 & 1318 \\
$\mathrm{~T}_{4}$ & 184 & 26.5 & 25 & 21.7 & 1300 \\
$\mathrm{~T}_{5}$ & 183 & 25.8 & 25 & 21.4 & 1252 \\
\hline LSD $(0.05)$ & 5.18 & 1.10 & 2.10 & 0.10 & 62.36 \\
$\mathrm{CV}(\%)$ & 6.8 & 3.7 & 5.3 & 5.9 & 9.1 \\
\hline
\end{tabular}

$\mathrm{T}_{1}=$ Sole Lentil $(100 \%), \mathrm{T}_{3}=$ Lentil $(100 \%)+$ Cowpea $(10 \%), \mathrm{T}_{4}=$ Lentil $(100 \%)+$ Cowpea $(20 \%), \mathrm{T}_{5}$ $=$ Lentil $(100 \%)+$ Cowpea $(30 \%)$

The maximum lentil seed yield was recorded in sole situation $T_{1}\left(1325 \mathrm{~kg} \mathrm{ha}^{-1}\right)$ which was statistically similar with $\mathrm{T}_{3}\left(1318 \mathrm{~kg} \mathrm{ha}^{-1}\right)$ and $\mathrm{T}_{4}\left(1300 \mathrm{~kg} \mathrm{ha}^{-1}\right)$ (Table 1$)$. It might be due to cumulative effect of yield contributing characters of lentil i.e. number of pods plant ${ }^{-1}$ and 1000 seed weight $(\mathrm{g})$. The lowest lentil yield was recorded in the treatment $\mathrm{T}_{5}\left(1252 \mathrm{~kg} \mathrm{ha}^{-1}\right)$ where $100 \%$ lentil broadcasted with $30 \%$ cowpea in the mixed cropping situation. The seed yield of lentil decreased with the increasing of cowpea population in the mixed cropped situation. It might be due to competition for nutrients and less light interception between the main and the intercrops.

\section{Seed yield and yield attributes of cowpea}

Yield and yield attributes of cowpea are presented in the Table 2. Results indicated that plant populations of cowpea were varied with the percent amount of seeds used among the treatments.

Table 2. Seed yield and yield attributes of cowpea as a mixed crop with lentil at South Lemua under MLT site, Feni during Rabi season of 2015-16

\begin{tabular}{lcccccc}
\hline Treatments & $\begin{array}{c}\text { Plant } \\
\text { height } \\
(\mathrm{cm})\end{array}$ & $\begin{array}{c}\text { Plants } \\
\mathrm{m}^{-2} \\
(\text { no. })\end{array}$ & $\begin{array}{c}\text { Pods plant }^{-1} \\
(\text { no. })\end{array}$ & $\begin{array}{c}\text { Seeds } \\
\text { pod }^{-1} \\
\left(\mathrm{no.}^{2}\right.\end{array}$ & $\begin{array}{c}\text { 1000- seeds } \\
\text { weight } \\
(\mathrm{g})\end{array}$ & $\begin{array}{c}\text { Seed yield } \\
\left(\mathrm{Kg} \mathrm{ha}^{-1}\right)\end{array}$ \\
\hline $\mathrm{T}_{2}$ & 47.7 & 32 & 9 & 11 & 91 & 866 \\
$\mathrm{~T}_{3}$ & 51.0 & 5 & 11 & 13 & 94 & 96 \\
$\mathrm{~T}_{4}$ & 51.8 & 9 & 12 & 14 & 94 & 221 \\
$\mathrm{~T}_{5}$ & 49.6 & 12 & 10 & 12 & 93 & 251 \\
\hline LSD $(0.05)$ & 6.59 & 3.15 & 0.99 & 1.70 & $\mathrm{NS}$ & 39.7 \\
$\mathrm{CV}(\%)$ & 8.6 & 7.2 & 6.4 & 3.1 & 6.1 & 8.5 \\
\hline
\end{tabular}

$\mathrm{T}_{2}=$ Sole Cowpea $(100 \%), \mathrm{T}_{3}=$ Lentil $(100 \%)+$ Cowpea $(10 \%), \mathrm{T}_{4}=$ Lentil $(100 \%)+$ Cowpea $(20 \%)$, $\mathrm{T}_{5}=$ Lentil $(100 \%)+$ Cowpea $(30 \%)$

The maximum number of pods plant ${ }^{-1}$ (12) was recorded in $T_{4}$ which was followed by $T_{3}$ treatment. The lowest number of pod plant ${ }^{-1}$ (9) was obtained from $\mathrm{T}_{2}$ (sole cowpea). The number of seeds pod $^{-1}$ varied significantly among the treatments. The maximum number of seeds pod ${ }^{-1}$ (14) was recorded in $\mathrm{T}_{4}$ which was statistically similar with $\mathrm{T}_{3}$ treatment. The lowest number of seeds pod $^{-1}$ (11) was recorded in the treatment $T_{2}$. Seed weight did not varied significantly. The highest seed yield of cowpea $\left(866 \mathrm{~kg} \mathrm{ha}^{-1}\right)$ was recorded in $\mathrm{T}_{2}$ (sole cowpea) which was significantly different from other treatments where lowest seed yield $\left(96 \mathrm{~kg} \mathrm{ha}^{-1}\right)$ was obtained from $\mathrm{T}_{3}$ treatment where only $10 \%$ cowpea seed was used.

\section{Lentil equivalent yield (LEY) and land equivalent ratio (LER)}


All the mixed crop treatments produced better lentil equivalent yield than their respective sole crop cultivation (Table 3). Lentil equivalent yield was increased with the increasing of cowpea seed for mixed cultivation up to 20 with $100 \%$ of lentil and thereafter it was declined with further increment of percent seeds. It might be due to excess inter plant competition for nutrients, light, water and space. The highest lentil equivalent yield of $1438 \mathrm{~kg} \mathrm{ha}^{-1}$ was obtained from lentil $(100 \%)+$ cowpea ( $20 \%$ ) combination, which was 9 and $166 \%$ higher than the sole crop of lentil and cowpea, respectively (Table 3 ). The results indicated that lentilcowpea mixed cropping could bring more benefit to farmers over sole lentil or cowpea. The maximum land equivalent ratio (LER) 1.24 was observed from the $\mathrm{T}_{4}$ treatment followed by $\mathrm{T}_{5}$ (1.23). It is noted that all the mixed cropping systems showed higher LER than sole crop(Table 3). It could be said that a farmer may increase his land use efficiency by $24 \%$ from mixed cropping systems from growing one hectare of land than that of their traditional sole crops cultivation. The results are in agreement with that Razzaque et al. (2007) and Alom et al. (2008).

Table 3. Lentil equivalent yield (LEY) and land equivalent ratio (LER) of mixed cropping of lentil with cowpea obtained from the experiment conducted at South Lemua under MLT site, Feni during Rabi season of 2015-16

\begin{tabular}{lccccc}
\hline \multirow{2}{*}{ Treatments } & \multicolumn{2}{c}{ Seed yield $\left(\mathrm{Kg} \mathrm{ha}^{-1}\right)$} & \multicolumn{2}{c}{$\begin{array}{c}\text { LEY } \\
\left(\mathrm{Kg} \mathrm{ha}^{-1}\right)\end{array}$} & \\
\cline { 2 - 3 } & Lentil & Cowpea & \\
\hline $\mathrm{T}_{1}=$ Sole Lentil $(100 \%)$ & 1325 & - & 1325 & 1.00 \\
$\mathrm{~T}_{2}=$ Sole Cowpea $(100 \%)$ & - & 866 & 541 & 1.00 \\
$\mathrm{~T}_{3}=$ Lentil $(100 \%)+$ Cowpea $(10 \%)$ & 1318 & 96 & 1378 & 1.10 \\
$\mathrm{~T}_{4}=$ Lentil $(100 \%)+$ Cowpea $(20 \%)$ & 1300 & 221 & 1438 & 1.24 \\
$\mathrm{~T}_{5}=$ Lentil $(100 \%)+$ Cowpea $(30 \%)$ & 1252 & 251 & 1410 & 1.23 \\
\hline
\end{tabular}

\section{Cost and Return Analysis}

Cost and return analysis are presented in the Table 4. Gross return as well as net return was found higher in mixed crop cultivation in comparison to sole cropping. From cost and return analysis, it was observed that $\mathrm{T}_{4}$ treatment showed the highest gross margin (Tk. 77,890 ha-1) followed by $\mathrm{T}_{5}\left(\mathrm{Tk} .75,425 \mathrm{ha}^{-1}\right)$. The lowest gross return (Tk. 43,280 ha ${ }^{-1}$ ) and gross margin (Tk. $7530 \mathrm{ha}^{-1}$ ) were obtained from sole cowpea. The highest benefit cost ratio (3.09) was recorded from $\mathrm{T} 4$ where as the minimum $\mathrm{BCR}$ (1.21) from sole cowpea $\mathrm{T}_{2}$ treatment. It is also showed that lentil is found better benefit than cowpea as sole crop in Feni region.

Table 4. Cost and return analysis obtained from the experiment conducted at South Lemua under MLT site, Feni during Rabi season of 2015-16

\begin{tabular}{|c|c|c|c|c|c|}
\hline Treatments & $\begin{array}{c}\text { Lentil } \\
\text { equivalent } \\
\text { yield } \\
\left(\mathrm{Kg} \mathrm{ha}^{-1}\right)\end{array}$ & $\begin{array}{l}\text { Gross } \\
\text { return } \\
(\mathrm{Tk} . \\
\left.\mathrm{ha}^{-1}\right)\end{array}$ & $\begin{array}{c}\text { Total } \\
\text { Cost } \\
\left(\begin{array}{c}\text { Tk. ha } \\
1\end{array}\right)\end{array}$ & $\begin{array}{l}\text { Gross } \\
\text { margin } \\
\left(\begin{array}{c}\text { Tk. ha } \\
1\end{array}\right)\end{array}$ & $\begin{array}{l}\text { Benefit } \\
\text { cost } \\
\text { ratio } \\
(\mathrm{BCR})\end{array}$ \\
\hline $\mathrm{T}_{1}=$ Sole Lentil $(100 \%)$ & 1325 & 106000 & 36700 & 69300 & 2.88 \\
\hline $\mathrm{T}_{2}=$ Sole Cowpea $(100 \%)$ & 541 & 43280 & 35750 & 7530 & 1.21 \\
\hline $\mathrm{T}_{3}=\operatorname{Lentil}(100 \%)+$ Cowpea $(10 \%)$ & 1378 & 110240 & 36925 & 73315 & 2.98 \\
\hline $\mathrm{T}_{4}=$ Lentil $(100 \%)+$ Cowpea $(20 \%)$ & 1438 & 115040 & 37150 & 77890 & 3.09 \\
\hline $\mathrm{T}_{5}=$ Lentil $(100 \%)+$ Cowpea $(30 \%)$ & 1410 & 112800 & 37375 & 75425 & 3.01 \\
\hline
\end{tabular}

Price of Lentil per $\mathrm{Kg}=\mathrm{Tk} .80$ and Cowpea per $\mathrm{Kg}=\mathrm{Tk} .50 /-$ 


\section{Conclusion}

Considering the yield and return it can be concluded that $100 \%$ lentil with $20 \%$ cowpea is the most profitable one as compared to other treatment combination when grown as mixed crop. From the results, it is evident that mixed cropping of lentil with cowpea is more profitable than the sole cropping and the risk of cultivation of one crop can be reduced by adopting the mixed cropping system. Nonetheless, $100 \%$ lentil with $20 \%$ cowpea is the most profitable mixed crop compared to other treatment.

\section{References}

Bandyopadhyay, S. K. 1984. Nitrogen and Water Relations in Grain Sorghum Legume Intercropping Systems. Ph. D. Dissertation, Indian Agricultural Research Institute (IARI), New Delhi110012, India.

Bangladesh Bureau of Statistics (BBS). 2016. The Year Book of Agricultural Statistics of Bangladesh. Statistics Division, Ministry of Planning, Government of the People's Republic Bangladesh, Dhaka.p.39.

Bhowal,S.K,M.M.U. Chowdhury, M.S. Bhuiyan,A. H. M. A.Faisal, I. S. M. Farhadand S.K. Bhowmik.2014.Yield and Yield Attributes of Lentil (Lens Esculenta) as a Mixed Crop with Mustard (Brassica Campestris). Sci. Agri. 4 (2): 76-79.

Das, S. and W. Kabir. 2016. Pulses production in Bangladesh: status and drivers for enhancement [version 1; not peer reviewed]. F1000Research 2016, 5: 2650 (poster).

Razzaque, M. A., S. Rafiquzzaman, M. M. M. Bazzaz, A. Ali and M. M. R. Talukdar. 2007. Study on the intercropping groundnut with chilli at different plant populations. Bangladesh J. Agril. Res. 32(1): 37-43.

Willey, R. W. and M. R. Rao. 1981. A competitive ratio for quantifying competition between intercrops. Expt. Agric. 16: 117-125. 